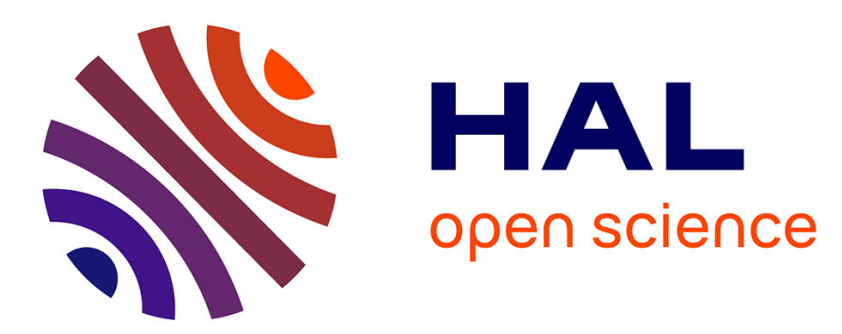

\title{
Bioaccumulation and metabolisation of 14C-pyrene by the Pacific oyster Crassostrea gigas exposed via seawater
}

Paco Bustamante, Andrea Luna-Acosta, Sarah Clamens, Roberto Cassi, Hélène Thomas-Guyon, Michel Warnau

\section{- To cite this version:}

Paco Bustamante, Andrea Luna-Acosta, Sarah Clamens, Roberto Cassi, Hélène Thomas-Guyon, et al.. Bioaccumulation and metabolisation of 14C-pyrene by the Pacific oyster Crassostrea gigas exposed via seawater. Chemosphere, 2012, 87 (8), pp.944-950. 10.1016/j.chemosphere.2012.01.049 . hal00682281

\section{HAL Id: hal-00682281 \\ https://hal.science/hal-00682281}

Submitted on 24 Mar 2012

HAL is a multi-disciplinary open access archive for the deposit and dissemination of scientific research documents, whether they are published or not. The documents may come from teaching and research institutions in France or abroad, or from public or private research centers.
L'archive ouverte pluridisciplinaire HAL, est destinée au dépôt et à la diffusion de documents scientifiques de niveau recherche, publiés ou non, émanant des établissements d'enseignement et de recherche français ou étrangers, des laboratoires publics ou privés. 
1 Bioaccumulation and metabolisation of ${ }^{14} \mathrm{C}$-pyrene by the Pacific oyster 2 Crassostrea gigas exposed via seawater

3

4

5 Bustamante $\mathrm{P}^{1^{*}}$, Luna-Acosta $\mathrm{A}^{1}$, Clemens $\mathrm{S}^{1-2}$, Cassi $\mathrm{R}^{2}$, Thomas-Guyon $\mathrm{H}^{1}$, Warnau $\mathrm{M}^{2}$ 6

7

8

10

$11{ }^{2}$ IAEA - Environement Laboratories, 4 Quai Antoine Premier - MC-98000 - Principality of 12 Monaco

13

14

15 *Corresponding author: Prof. Paco Bustamante

16

17

18

19
Phone: $+33-546-507-625$

Fax: +33-546-458-264

E-mail: pbustama@univ-lr.fr 
Abstract: The first objective of this study was to determine the bioaccumulation kinetics of pyrene in the soft tissues of Crassostrea gigas (mantle, muscle, gills, digestive gland, and the remaining soft tissues). As bivalves can biotransform hydrocarbons in more polar compounds (metabolites) that are more easily excreted, the second objective was to investigate the oyster capacity to metabolize pyrene into its metabolite, the 1-hydroxypyrene. To these ends, oysters were exposed $24 \mathrm{~h}$ to waterborne ${ }^{14} \mathrm{C}$-pyrene then placed in depuration conditions for $15 \mathrm{~d}$. Oysters efficiently bioaccumulated pyrene in their soft tissues and equilibrium was reached within the exposure time. The metabolite1-hydroxypyrene was also detected in oyster tissues but represented only 4 to $14 \%$ of the parent pyrene. At the end of the exposure period, the gills and the mantle showed the highest pyrene proportion of total soft tissue content, i.e. $47 \%$ and $26 \%$, respectively. After $15 \mathrm{~d}$ of depuration, the mantle contained $32 \%$ and $30 \%$ of the remaining pyrene and 1-hydroxypyrene, respectively. As C. gigas did not display a high capacity for metabolizing pyrene, it can be considered as a good bioindicator species to survey and monitor pyrene contamination in the coastal marine environment.

Keywords: polycyclic aromatic hydrocarbons; bivalve; tissue distribution; bioaccumulation; kinetics 


\section{Introduction}

Polycyclic aromatic hydrocarbons (PAHs) are found in many common products, such as petrol, fumes and household heating (e.g. using oil, gas or wood). Petroleum spills and discharges, seepages, industrial and municipal wastewater, urban and suburban surface runoff, and atmospheric deposition contribute to aquatic contamination caused by PAHs (Eisler, 1987). During the last decades, many studies have monitored the inputs, fluxes and fate of PAHs in the marine environment (Obana et al. 1983; Baumard et al. 1999). However, in order to assess the state of the marine ecosystem, it is necessary to know the fraction of these compounds which can be taken up by aquatic biota and their potential toxic effects (Escartin and Porte, 1999).

The quality of aquatic environments can be assess through the analysis of organisms considered as indicators of pollution, such as oysters, mussels and other bivalve molluscs (Pereira et al. 1992; Jaffé et al. 1995; Lauenstein, 1995; Beliaeff et al. 1997; Gunther et al. 1999). Indeed, because of their biological (e.g. capacity of bioaccumulation, resistance to physico-chemical stresses) and ecological characteristics (e.g. worldwide distribution, abundance of their populations), bivalves are among the best candidates to be bioindicator species (Phillips, 1976; Farrington and Tripp, 1993). These organisms can bioaccumulate a large variety of pollutants at levels higher than those present in the surrounding waters or sediments, and their behaviour can be recorded in short periods of time (Baumard et al. 1998; Solé et al. 2000). In this way, mussels have been extensively used worldwide as sentinel organisms to monitor the uptake and accumulation of PAHs in the coastal environments, in the Mussel Watch Program in the USA (O'Connor 1996, O'Connor and Lauenstein 2006), the Coordinated Environmental Monitoring Program (OSPAR 2010) and the Réseau National de la Contamination CHimique (ROCCH 2008) in France. In this last country, oysters are also 
used as a sentinel species in the ROCCH monitoring program, which is particularly relevant in areas where mussels are absent.

The exposure of marine organisms to PAHs has often been evaluated by measuring tissue contaminant contents (Varanasi et al. 1989). However, when considering biotransformation capacities of these organisms, this approach becomes less relevant. Indeed, biotransformation refers to the entire modification of chemical molecules occurring in the organisms. Metabolism of PAHs in marine invertebrates is apparently related to cytochrome P450 (EC 1.14.14.1). This enzyme converts parent hydrophobic and lipid-soluble PAHs, into water soluble metabolites. However, the mechanisms by which the involved enzymes are regulated are still poorly understood (Hahn, 1998). In marine mammals and birds, some studies have shown that the low concentrations of PAHs in their tissues were due to a combination of inefficient bioaccumulation from food and rapid metabolisation and excretion of accumulated PAHs (Watanabe et al. 1989; Fossi et al. 1995). In the common sole Solea solea affected by a strong PAH pollution, the liver produced metabolites that were released through the bile (Budzinski et al. 2004). Previously, it was believed that molluscs possessed a weak to nonexistent ability to metabolize PAHs (Lee et al. 1972a; Palmork and Solbakken, 1981). Conversely, molluscs may have relatively strong metabolisation systems (McElroy et al. 2000) and it has been shown that molluscs collected in strongly polluted environments contained often low concentrations of PAHs (e.g. Varanasi et al. 1989; Baumard, 1997).

The Pacific oyster Crassostrea gigas (Thunberg, 1793) has a high economic value in the world and especially in France. Indeed, most of French oyster-farming raise this species which production averages up to 128000 tonnes per year (CNC, 2004). Many farmhouses exist all along the French coastline and they are very sensitive to marine contamination, especially during oil slicks. It is therefore fundamental to better understand the mechanisms of bioaccumulation of PAHs in this species. 
Various studies have shown that pyrene and other PAHs with four benzene rings are among the most predominant PAHs in bivalves (Obana et al. 1983; Varanasi et al. 1985; Wade et al. 1988; Kaag et al. 1997). Moreover, pyrene is considered as one of the 16 most toxic contaminants for the environment and the dominant PAHs in the marine environment (Giessing et al. 2003). Therefore, the first aim of this study was to follow the kinetics of uptake and depuration of pyrene in the organs and tissues of $C$. gigas exposed via seawater. In order to study environmentally realistic contaminant levels, the pyrene used was ${ }^{14} \mathrm{C}$-labelled and measured using highly sensitive radiodetection technique. The second objective of this work was to determine the presence and the kinetics of formation of 1-hydroxypyrene, i.e. the pyrene metabolite previously demonstrated to be predominant in fish bile (e.g. Krahn et al. 1987; Ariese et al. 1993),

\section{Materials and methods}

\subsection{Biological material}

Oysters were purchased from a shellfish farm on the French Atlantic coast (La Rochelle). Organisms were then transferred to the Environment Laboratories premises (IAEA, Monaco). Prior to the experimentation, specimens were acclimated to laboratory conditions for two months (constantly aerated open-circuit aquarium; salinity: $36 \pm 1$ p.s.u.; temperature: $19 \pm 1$ ${ }^{\circ} \mathrm{C}$; pH: 8; light/dark cycle: $12 \mathrm{~h} / 12 \mathrm{~h}$ ). During acclimation, bivalves were fed phytoplankton using the Prymnesiophyceae Isochrysis galbana $\left(10^{4}\right.$ cells $\left.\mathrm{ml}^{-1}\right)$. Recorded mortality was lower than $5 \%$ over the acclimation period.

\subsection{Radiotracer and radioanalyses}

The ${ }^{14}$ C-labelled 4, 5, 9, 10 pyrene was purchased from Sigma, USA. Specific activity was

$2.1710^{9} \mathrm{~Bq} \mathrm{mmol}^{-1}$. Stock solutions were prepared in methanol and a final concentration of $27 \mu \mathrm{g} \mathrm{L}{ }^{-1}$ was used. 
113 Two $\mathrm{mL}$ of the mixtures containing pyrene and 1-hydroxypyrene or purified pyrene samples

114 (see below) were transferred to $20 \mathrm{~mL}$ glass scintillation vials (Packard) and mixed with 10

$115 \mathrm{~mL}$ of scintillation liquid (Ultima Gold, Packard). ${ }^{14} \mathrm{C}$-radioactivity was measured using a

1161600 TR Liquid Scintillation Analyser (Packard). Activity was determined by comparison

117 with standards of known activities and measurements were corrected for counting efficiency

118 and quenching effect. Counting time was adjusted to obtain a propagated counting error less

119 than $5 \%$.

120

$121 \quad$ 2.3. Experimental procedure

$122 \quad$ 2.3.1. Uptake phase

123 Forty four oysters were placed in a 50L glass aquarium containing natural seawater (closed

124 circuit) spiked with ${ }^{14} \mathrm{C}$-labelled pyrene. The initial pyrene concentration in the aquarium was

$1250.27 \mu \mathrm{g} \mathrm{L}^{-1}$. This concentration matches with PAHs values found in strongly polluted areas

126 (Axelman et al. 1999). Every 30 minutes, seawater radioactivity was measured and pyrene

127 was added as required in order to keep its concentration constant during the whole

128 accumulation phase $(24 \mathrm{~h})$. Oysters were not fed during the exposure period. Four animals

129 were collected at different times $(0,2,5,9,19$ and $24 \mathrm{~h})$ in order to follow the uptake kinetics

130 of ${ }^{14} \mathrm{C}$-pyrene and the formation of its metabolite. At the end of the exposure period (24h),

131 seawater was sampled to detect whether metabolites could have been released by exposed

132 animals.

133 At each sampling time, oyster soft tissues were dissected into five compartments: mantle,

134 gills, muscle, digestive gland and remaining tissues (i.e., labial palps, gonad and heart). Each

135 organ and tissue was weighed and crushed. Then, samples were treated with $200 \mu \mathrm{L}$ of $\beta$ -

136 glucuronidase-aryl-sulfatase mixture containing 100000 units $\mathrm{mL}^{-1}$ of glucuronidase (Sigma)

137 and 7500 units $\mathrm{mL}^{-1}$ of sulfatase (Sigma) for enzymatic deconjugation. To this purpose, the 
samples were buffered to $\mathrm{pH} 5$ with $3 \mathrm{~mL}$ of $5 \mathrm{M}$ potassium acetate buffer. They were then

139 placed in an oven at $37^{\circ} \mathrm{C}$ during 20 hours.

140 Pyrene and 1-hydroxypyrene were extracted via two subsequent liquid/liquid extractions. The

141 first extraction was performed by adding $5 \mathrm{~mL}$ of a hexane/dichloromethane solution (50:50)

142 and the second extraction was performed by adding $4 \mathrm{~mL}$ of a methanol/dichloromethane

143 solution (10:90) to extract pyrene and 1-hydroxypyrene, respectively. For both extractions,

144 the samples were mechanically shaken for 30 minutes and then centrifuged at $6000 \mathrm{rpm}$ for 5

145 minutes. In the first extraction, the organic phase $(5 \mathrm{~mL})$ was recovered in a flat bottom flask.

146 Following the second extraction, the organic phase was recovered and combined with the first

147 one. Two $\mathrm{mL}$ of the extracted solution was radioanalysed to determine the amount of pyrene

$148+1$-hydroxypyrene in each organ.

149 The rest of the mixture was concentrated under a gentle stream of nitrogen to $1 \mathrm{~mL}$ and then

150 separated by using upti-clean SPE glass columns Si/Cn-S (Interchim, Montluçon, France).

151 Pyrene was eluted with $5 \mathrm{~mL}$ of a hexane/dichloromethane (50:50) solution which was

152 radioanalysed.

153 The 1-hydroxypyrene content in each organ was calculated by comparing the results of the 154 two radioanalyses.

\section{$156 \quad$ 2.3.2. Depuration phase}

157 At the end of the exposure period, the remaining organisms were placed in an open circuit

158 50L seawater aquarium (salinity: $36 \pm 1$ p.s.u.; temperature: $19 \pm 1{ }^{\circ} \mathrm{C}$; $\mathrm{pH}$ : 8 ; light/dark cycle:

$15912 \mathrm{~h} / 12 \mathrm{~h})$. At different times of the depuration period $(0,6,18,36,96,192$ and $336 \mathrm{~h})$ four

160 oysters were collected and their soft tissues dissected in order to follow the variation in 161 pyrene and its metabolite. The dissected tissues and organs were processed according to the

162 same method as previously described. 


\subsection{Data analyses}

\section{$164 \quad$ 2.4.1. Uptake kinetics}

165 A first order model was used to assess changes in pyrene concentration in oyster tissues along

166 time during the exposure to waterborne pyrene. In this model the change in tissue activity

167 with time was calculated by:

168

169

$$
\mathrm{dA}_{\text {org }} / \mathrm{dt}=\mathrm{k}_{\mathrm{u}} \mathrm{A}_{\mathrm{SW}}-\mathrm{k}_{\mathrm{e}} \mathrm{A}_{\mathrm{org}}
$$

170

171 where $\mathrm{A}_{\text {org }}=$ activity of pyrene in tissue $\left(\mathrm{Bq} \mathrm{g}^{-1}\right.$ tissue $)$

$172 \mathrm{~A}_{\mathrm{SW}}=$ activity of pyrene in seawater $\left(\mathrm{Bq} \mathrm{g}^{-1}\right.$ water $)$

$173 \mathrm{k}_{\mathrm{u}}=$ uptake rate constant $\left(\mathrm{Bq} \mathrm{g}^{-1} \mathrm{~h}^{-1}\right)$

$174 \mathrm{k}_{\mathrm{e}}=$ elimination rate constant $\left(\mathrm{Bq} \mathrm{g}^{-1} \mathrm{~h}^{-1}\right)$

$175 \mathrm{t}=$ time $(\mathrm{h})$

176

177 As $\mathrm{A}_{\mathrm{SW}}$ was maintained constant during the uptake experiment phase, Eq. (1) can be 178 integrated to estimate tissue activities at any exposure time by:

179

180

$$
A_{\text {org }} t=A_{S W}\left(k_{u} / k_{e}\right)\left(1-e^{-k_{e} t}\right)
$$

181

182 where $\mathrm{A}_{\text {org }} \mathrm{t}=$ tissue activity at time $t$

183

184 When steady-state tissue activities are attained (i.e. $\mathrm{dA}_{\mathrm{org}} / \mathrm{dt}=0$ ), the bioconcentration factor 185 (BCF) can be estimated as follows:

186

187

$$
\mathrm{A}_{\text {org }} / \mathrm{A}_{\mathrm{SW}}=\mathrm{BCF}=\mathrm{k}_{\mathrm{u}} / \mathrm{k}_{\mathrm{e}}
$$


189 In this study, the $\mathrm{BCF}$ is the ratio between ${ }^{14} \mathrm{C}$-labelled pyrene in the body and in the surrounding seawater.

\subsubsection{Depuration kinetics}

193 The depuration kinetics were best fitted using either a single-component exponential equation

194 (Eq.(4)) or a double-component exponential equation (Eq.(5)):

195

196

197

$$
A_{t}=A_{0}\left(e^{-k_{e} t}\right)
$$

$$
A_{t}=A_{0 s}\left(e^{-k_{e s} t}\right)+A_{01}\left(e^{-k_{e l} t}\right)
$$

198

199 where $\mathrm{A}_{\mathrm{t}}=$ remaining activity at time $t\left(\mathrm{~Bq} \mathrm{~g}^{-1}\right)$

$200 \mathrm{~A}_{0}=$ activity at time $O\left(\mathrm{~Bq} \mathrm{~g}^{-1}\right)$, i.e. at the beginning of the depuration period

$201 \mathrm{k}_{\mathrm{e}}=$ depuration rate constant $\left(\mathrm{Bq} \mathrm{g}^{-1} \mathrm{~h}^{-1}\right)$

202

For double-component exponential model (Eq. 5), a 'short-lived' component $(s)$ and a long-

206 be calculated $\left(\mathrm{T}_{\mathrm{b} 1 / 2 \mathrm{~s}}\right.$ and $\left.\mathrm{T}_{\mathrm{b} 1 / 21}\right)$ from the corresponding depuration rate constants $\left(\mathrm{k}_{\mathrm{es}}\right.$ and $\mathrm{k}_{\mathrm{el}}$, 207 respectively) according to the relation:

$$
\mathrm{T}_{\mathrm{b} 1 / 2}=\ln 2 / \mathrm{k}_{\mathrm{e}}
$$


214 Model constants and their statistics were estimated by iterative adjustment of the model using

215 the nonlinear curve-fitting routines in the Statistica 6 software. For depuration kinetics, best

216 fitting models were selected between single- and double-component exponential equation,

217 according to the highest determination coefficient and examination of residuals. The level of 218 significance for statistical analyses was always set at $\alpha=0.05$.

\section{Results}

\subsection{Seawater exposure}

222 Uptake of pyrene in five body compartments (mantle, gills, muscle, digestive gland and 223 remaining tissues) of $C$. gigas exposed to spiked seawater for $24 \mathrm{~h}$ is presented in Fig. 1 . The 224 parameters and statistics of the uptake kinetic of ${ }^{14} \mathrm{C}$-pyrene are summarized in Table 1 . The 225 steady-state BCF of pyrene in the whole soft parts of the oysters was observed within $24 \mathrm{~h}$ and 226 reached $1560 \pm 630$ (Table 1). Among the tissues, the gills accumulated rapidly and strongly 227 the contaminant with a BCF of $2080 \pm 860$. However, each organ accumulated the pyrene in a 228 different way (Fig. 1). For example, during the uptake phase, the mantle and the remaining 229 tissues efficiently accumulated waterborne pyrene but the state of equilibrium was not 230 reached during the time frame of the experiment (Fig. 1).

231 The final distribution of the contaminant in each compartment after $24 \mathrm{~h}$ of exposure is 232 presented in Fig. 2. Among tissues, gills contained half of the whole body burden 233 radioactivity and consistently showed the highest rate of accumulation with a $\mathrm{k}_{\mathrm{u}}$ of $433 \mathrm{~Bq} \mathrm{~g}^{-1}$ $234 \mathrm{~h}^{-1}$ (Table 1). In contrast, the muscle was the organ with the lower rate of accumulation $\left(\mathrm{k}_{\mathrm{u}}=\right.$ $\left.23538 \mathrm{~Bq} \mathrm{~g}^{-1} \mathrm{~h}^{-1}\right)$ and thus, only contained a very low proportion $(5 \%)$ of the total quantity of ${ }^{14} \mathrm{C}$ 236 pyrene present in oyster soft tissues (Fig. 2). 
237 Quantification of the pyrene metabolites was carried out at each sampling time, and the 238 proportion of 1-hydroxypyrene represented between 4 and 14\% of the total radioactivity (Fig. $2393)$.

240 At the end of the exposure period, the concentration of 1-hydroxypyrene in seawater was 241 below the detection limit of the method.

\subsection{Depuration phase}

At the end of the exposure time, non-contaminating conditions were restored and depuration kinetics of the pyrene were followed in the organs and tissues of the oysters for $15 \mathrm{~d}$. The loss of incorporated ${ }^{14} \mathrm{C}$-labelled pyrene followed a single or a double exponential model in the different body compartments (Fig. 4 and Table 2). In the muscle, gills and mantle, depuration was best described by a double-component exponential equation $\left(\mathrm{R}^{2}=0.42,0.52\right.$ and 0.48 , respectively). The resulting biological half-lives $\left(\mathrm{T}_{\mathrm{b} 1 / 2}\right)$ ranged from 1.17 (mantle) to 9.35 hours (gills) for the short-lived compartment and from 2.75 (muscle) to 7.27 days (gills) for the long-lived compartment (Table 2). In contrast, a single-component exponential equation

252 better fitted the depuration kinetics in the digestive gland and in the remaining tissues $\left(\mathrm{R}^{2}\right.$ $253=0.37$ and 0.30 , respectively). They were characterized by a relatively strong retention of 254 pyrene: the resulting $\mathrm{T}_{\mathrm{b} 1 / 2}$ were 87.4 and 97.4 hours, respectively, (i.e., 3.64 and 4.05 days) 255 (Table 2, Fig. 4).

256 The distribution of ${ }^{14} \mathrm{C}$-labelled pyrene among the oyster soft tissues was determined at the 257 end of the depuration period (Fig. 5). It differed from the distribution observed at the end of 258 the exposure period (Fig. 2), with a lower fraction associated to the gills $(24 \pm 10$ vs. $47 \pm$ $25913 \%)$ and a higher fraction associated to the digestive gland $(19 \pm 10$ vs. $6 \pm 4 \%)$ and the 260 remaining tissues $(21 \pm 18$ vs. $16 \pm 3 \%)$. At the end of the depuration period, the digestive 261 gland displayed the highest pyrene activity (data not shown). In contrast, the gills had lost 
$50 \%$ of their activity during the depuration phase. Figure 5 also shows the distribution of 1-

263 hydroxypyrene between the body compartments at the end of the depuration period. 1hydroxypyrene was distributed in similar proportion as pyrene in the oyster body compartments.

\section{Discussion}

Oysters accumulated very efficiently the ${ }^{14} \mathrm{C}$-labelled waterborne pyrene following a saturation model and after a short exposure period (24h), organisms reached the state of equilibrium. Among soft tissues, the gills accumulated rapidly and strongly the contaminant with a BCF of 2080 (Table 1) likely because of the high filtration rate of oysters which could be as high as 3.9 $\mathrm{L} \mathrm{h}^{-1} \mathrm{~g}^{-1}$ dry weight (Bougrier et al. 1995). Consequently, the gills displayed the highest activities at the end of the exposure phase. Absorption of pyrene onto gills might be facilitated in oysters, as it occurs in blue mussels Mytilus edulis which have a micellar layer which absorbs hydrocarbons (Lee et al. 1972a). Nevertheless, the accumulated pyrene was relatively rapidly lost from this tissue (Table 1). Indeed, pyrene proportion in the gills at the end of the depuration phase was half than at the end of the exposure period (Figs. 2 and 5). This decrease is due to a fast depuration rate of pyrene in the gills (Table 1). At the same time, the increase of pyrene proportions in the digestive gland and remaining tissues suggest that it was transferred towards from the gills to these tissues as previously reported in other organisms (Neff, 1979). Therefore, the decrease of pyrene observed in the gills was also due to a relative increase of the activity in other compartments, such as the digestive gland (data not shown).

During the uptake phase, the mantle and the remaining tissues also accumulated pyrene but the steady-state was not reached for these compartments. This is probably due to the fact that, even if these tissues are in contact with seawater, their surface is much smaller than that of the 
gills, and the cell types and the thickness of the epithelium differ completely (Auffret, 2003).

288 The resulting uptake rates $\left(\mathrm{k}_{\mathrm{u}}\right)$ were lower for both tissues than for gills. During the 289 depuration phase, the mantle released pyrene quickly. In contrast, the remaining tissues 290 showed a slow increase of the pyrene proportion against the total pyrene content in oysters as 291 well as of its metabolite proportion (against the total metabolite content in oysters) during the 292 depuration period. It is well-known that tissues rich in lipids, e.g. gonads, accumulate preferentially PAHs because of the highly hydrophobic nature of the latter (Berthelin et al. 2000, Meador et al. 1995). Moreover, a strong increase of the activity in the remaining tissues was noticed during the third sampling in the depuration period $(\mathrm{t}=36 \mathrm{~h})$. The four oysters studied at this moment showed the particularity of being in the reproduction stage and of 297 having gonadic tissues more abundant than the average of other individuals. For this reason, 298 having acknowledged the unlikely hypothesis that these observations could come partly from an error of manipulation, it seems that this increase of activity was rather due to a stronger retention in mature gonadic tissues. This conclusion is consistent with results of Ellis et al. (1993), where gonads from $C$. virginica displayed PAH concentrations five times higher than 302 in somatic tissues.

303 In contrast, the digestive gland and the muscle which are not truly in direct contact with seawater displayed lower BCF than the gills, the mantle and the remaining tissues (Table 1).

305 Nevertheless, the uptake rate for the digestive gland was much higher than the one of the 306 muscle. The steady-state of pyrene in the digestive gland was reached very quickly, i.e. after $3079 \mathrm{~h}$ while it took $19 \mathrm{~h}$ in the muscle (Fig. 1). The results strongly suggest that during the 308 exposure period pyrene was transferred from tissues in contact with seawater such as gills, 309 towards the digestive gland. Moreover, the digestive gland showed a higher percentage of 1310 hydroxypyrene (19\%) in relation to total radioactivity (pyrene +1 -hydroxypyrene) than the 311 other organs (9-12\%) and the proportion of pyrene and its metabolite in the digestive gland 
312 increased from $6-10 \%$ at the end of the accumulation period to $19-24 \%$ at the end of

313 depuration period (Figs. 2 and 5). This suggests that the digestive gland had a stronger

314 metabolisation capacity of pyrene than the other tissues.

315 Among all the tissues studied, the digestive gland and the remaining tissues displayed the 316 strongest retention capacity with $\mathrm{T}_{\mathrm{b}^{1 / 2}}$ of 87.4 and $97.4 \mathrm{~h}$, respectively. Indeed, just like almost 317 all organic contaminants, PAHs best store up in some tissues, namely in the hepatopancreas in 318 invertebrates and in the liver in vertebrates (Meador et al. 1995). Because of their highly 319 hydrophobic nature, PAHs are mostly accumulated in tissues with high lipid contents. The 320 transformed PAH metabolites generally accumulate in the hepatopancreas (Lee et al. 1976; 321 Neff et al. 1976; Meador et al. 1995). It has been proved that for some invertebrates and for 322 several fish species exposed to PAHs either via water, food or sediments, the cytochrome 323 P450 enzymatic system connected to an oxygenase function (MFO) is activated in their 324 hepatic structure (Andersson and Forlin, 1992). In the case of fish, this enzymatic system 325 allows excreting most of the PAHs bioaccumulated via the bile and the urine (Pritchard and 326 Bend, 1991). This particular function was difficult to bring to light concerning bivalves. For a 327 long time, it was admitted that bivalves did not possess a P450 system (Lee et al. 1972b; 328 Vandermeulen and Penrose, 1978). However, more recent studies have shown that bivalves 329 do possess a P450 system (Lake et al. 1985; McLeese and Burridge, 1987), allowing them to 330 metabolize PAHs. As it is the case for the majority of marine invertebrates, such ability to 331 metabolize PAHs is weaker than for vertebrates (Livingstone, 1994; Stegeman and Hahn, 332 1994).

333 Data obtained on 1-hydroxypyrene in the tissues and organs of $C$. gigas seem to confirm that 334 metabolisation of pyrene in oysters is relatively weak and therefore would not be the driving 335 mechanism responsible for its elimination. It is however possible that because of the large 336 volumes of water they filter continuously, water-soluble metabolites would be rapidly 
excreted and, therefore, not accumulated in the tissues (James, 1989). If the event lasts only

338 for few days, it is very likely that most of the accumulated PAHs are going to be eliminated.

339 In contrast, Meador et al. (1995) suggested that, during a chronic exposure, a non negligible

340 fraction of the PAHs could be stored in lipids and become less subject to the elimination by

341 diffusion or by metabolisation.

342 In conclusion, $C$. gigas presents a good potential of bioaccumulation of the pyrene and seems

343 to have a low metabolisation capacity for this compound. Such a bioaccumulation capacity

344 suggests that $C$. gigas could be used as a valuable bioindicator for pyrene. Following a marine

345 contamination, oysters are thus able to rapidly accumulate the contaminant in detectable

346 concentrations. Besides, as this species is very common in several regions of the world,

347 samples can be collected at any time and in many countries. This makes the situation easier

348 for comparing data. However, its speed of depuration is also quick, thus it does not allow the

349 recording of long-term pollution. On the contrary, it is very interesting for the monitoring of

350 the pollution variations on short-term periods.

\section{Acknowledgments}

353 MW is an Honorary Senior Research Associate of the National Fund for Scientific Research 354 (NFSR, Belgium) and held a 2008-2009 Invited Expert position at LIENSs (CNRS-Université 355 de La Rochelle), supported by the Conseil Régional de Poitou-Charentes. This work was 356 supported by the IAEA and LIENSs. The IAEA is grateful for the support provided to its 357 Environment Laboratories by the Government of Monaco.

\section{References}

360 Andersson, T., Forlin, L., 1992. Regulation of the cytochrome P450 enzyme system in fish. 361 Aquat. Toxicol. 24, 1-20. 
Ariese, F., Kok, S.J., Verkaik, M., Gooijer, C., Verlthorst, N.H., Hofstraat, J.W., 1993.

363 Synchronous fluorescence spectrometry of fish bile: A rapid screening method for the 364 biomonitoring of PAH exposure. Aquat. Toxicol. 26, 273-286.

Auffret, M. 2003. Atlas of histology and cytology of marine molluscs. Grizel H (ed.) Ifremer,

366 Plouzane France.

367 Axelman, J., Naes, K., Naf, C., Broman, D., 1999. Accumulation of polycyclic aromatic 368 hydrocarbons in semipermeable membrance device and caged mussels (Mytilus edulis) in 369 relation to water column phase distribution. Environ. Toxicol. Chem. 18, 2454-2461.

370 Baumard, P., 1997. Biogéochimie des composés aromatiques dans l'environnement marin.

371 Thèse d'Université Bordeaux I, 290p.

372 Baumard, P., Budzinski, H., Garrigues, P., Sorbe, J.C., Burgeot, T., Bellocq, J., 1998. 373 Concentrations of PAHs (Polycyclic Aromatic Hydrocarbons) in various marine organisms in 374 relation to those in sediments and to trophic level. Mar. Pollut. Bull. 36, 951-960.

375 Baumard, P., Budzinski, H., Garrigues, P., Narbonne, J.F., Burgeot, T., Michel, X., Bellocq, 376 J., 1999. Polycyclic aromatic hydrocarbons (PAH) burden of mussels (Mytilus sp.) in different 377 marine environments in relation with PAH contamination, and bioavailability. Mar. Environ. 378 Res. 47, 415-439.

379 Beliaeff, B., O’Connor, T.P., Daskalakis, D.K., Smith, P.J., 1997. U.S. Mussel Watch data 380 from 1986 to 1994: Temporal trend detection at large spatial scales. Environ. Sci. Technol. 3, $381 \quad 1411-1415$.

382 Berthelin, C., Kellner, K., Mathieu, M., 2000. Storage metabolism in the Pacific oyster 383 (Crassostrea gigas) in relation to summer mortalities and reproductive cycle (West Coast of 384 France). Comp. Biochem. Physiol. 125B, 359-369. 
385 Bougrier, S., Geairon, P., Deslous-Paoli, J.M., Bacher, C., Jonquieres, G., 1995. Allometric 386 relationships and effects of temperature on clearance and oxygen consumption rates of 387 Crassostrea gigas (Thunberg). Aquaculture 134, 143-154.

388 Budzinski, H., Mazéas, O., Tronczynski, J., Désaunay, Y., Bocquené, G., Claireaux, G., 2004. 389 Link between exposure of fish (Solea solea) to PAHs and metabolites: Application to the 390 'Erika' oil spill. Aquat. Living Resour. 17, 329-334.

391 CNC 2004. Comité National de la Conchyliculture. Statistiques [on line] last accessed 392 February 2004. Available from World Wide Web: 393 http://www.cncfrance.com/actualite/Default.htm

394 Eisler, R., 1987. Polycyclic aromatic hydrocarbon hazards to fish, wildlife, and invertebrates: 395 a synoptic review. U.S. Fish and Wildlife Service Biological Report 85 (1.11).

396 Ellis, M.S., Choi, K.S., Wade, T.L., Powell, E.N., Jackson, T.J., Lewis, D.H., 1993. Sources 397 of local variations in polynuclear aromatic hydrocarbon and pesticides body burdens in 398 oysters (Crassostrea virginica) from Galveston bay, Texas. Comp. Biochem. Physiol. 100C, $399 \quad 689-698$.

400 Escartin, E., Porte, C., 1999. Assessment of PAH Pollution in Coastal Areas from the NW 401 Mediterranean through the analysis of Fish Bile. Mar. Pollut. Bull. 38, 1200-1206.

402 Farrington, J.W., Tripp, B.W., 1993. International Mussel Watch. Oceanus 36, 62-64.

403 Fossi, M.C., Massi, A., Lari, L., Marsili, L., Focardi, S., Leonzio, C., Renzoni, A., 1995. 404 Interspecies differences in mixed function oxidase activity in birds: relationship between 405 feeding habits, detoxification activities and organochlorine accumulation. Environ. Pollut. 90, $406 \quad 15-24$.

407 Giessing, A.M.B., Mayer, L.M., Forbes, T.L., 2003. Synchronous fluorescence spectrometry 408 of 1-hydroxypyrene: a rapid screening method for identification of PAH exposure in tissue 409 from marine polychaetes. Mar. Environ. Res. 56, 599-615. 
410 Gunther, A.J., Davis, J.A., Hardin, D.D., Gold, J., Bell, D., Crick, J.R., Scelfos, G.M.,

411 Sericano, J., Stephenson, M., 1999. Long-term bioaccumulation monitoring with transplanted

412 bivalves in the San Francisco estuary. Mar. Pollut. Bull. 38, 170-181.

413 Hahn, M.E., 1998. The aryl hydrocarbon receptor: A comparative perspective. Comp.

414 Biochem. Physiol. 121C, 23-53.

415 Jaffé, R., Leal, I., Alvarado, J., Gardinalis, P., Sericano, J., 1995. Pollution effects of the Tuy

416 river on the Central Venezuelan Coast: Anthropogenic organic compounds and heavy metals

417 in Tivela mactroidea. Mar. Pollut. Bull. 30, 820-825.

418 James, M.O., 1989. Biotransformation and disposition of PAH in aquatic invertebrates. In:

419 Varanasi U. (Ed.). Metabolism of polycyclic aromatic hydrocarbons in the aquatic 420 environment. CRC Press, Boca Raton, FL: 69-91.

421 Kaag, N.H.B.M., Foekema, E.M., Scholten, M.C.Th., Van Straalen, N.M., 1997. Comparison

422 of contaminant accumulation in three species of marine invertebrates with different feeding 423 habits. Environ. Toxicol. Chem. 16, 837-842.

424 Krahn, M.M., Burrows, D.G., MacLeod, W.D., Malins, D.C., 1987. Determination of 425 individual metabolites of aromatic compounds in hydrolysed bile of English sole (Parophrys 426 vetulus) from Puget Sound, Washington. Arch. Environ. Contam. Toxicol. 16, 511-522.

427 Lake, J., Hoffman, G.L., Schimmel, S.C., 1985. Bioaccumulation of contaminants from Black 428 Rock Harbor dredged material by mussels and polychaetes. Tech. Rep. D-85-2, U.S. 429 Environmental Protection Agency, Washington, DC. 156p.

430 Lauenstein, G.G., 1995. Comparison of organic contaminants founding mussels and oysters 431 from a current Mussel Watch Project with those from archived mollusk samples of the 1970s.

432 Mar. Pollut. Bull. 30, 826-833.

433 Lee, R.F., Sauerheber, R., Benson, A.A., 1972a. Petroleum hydrocarbons: uptake and 434 discharge by the marine mussel Mytilus edulis. Science 177, 344-346. 
Lee, R.F., Sauerheber, R., Dobbs, G.H., 1972b. Uptake, metabolism and discharge of 436 polycyclic aromatic hydrocarbons by marine fish. Mar. Biol. 37, 201-208.

437 Lee, R.F., Ryan, C., Neuhauser, M.L., 1976. Fate of petroleum hydrocarbons taken up from 438 food and water by the blue crab Callinectes sapidus. Mar. Biol. 37, 369-370.

439 Livingstone, D.R., 1994. Recent developments in marine invertebrates organic xenobiotic 440 metabolism. Toxicol. Ecotoxicol. News 1(3), 88-95.

441 McElroy, A., Leitch, K., Fay, A., 2000. A survey of in vivo benzo[a]pyrene metabolism in 442 small benthic marine invertebrates. Mar. Environ. Res. 50, 33-38.

443 McLeese, D.W., Burridge, L.E., 1987. Comparative accumulation of PAHs in four marine 444 invertebrates. In: Capuzzo J.M., Kesler D.R (Eds) Oceanic Processes in Marine Pollution. 445 Vol. I. Biological Processes and Wastes in the Oceans. Robert E. Krieger Publishing Co., 446 Malabar, FL: 109-117.

447 Meador, J.P., Stein, J.E., Reichert, W.L., Varanasi, U., 1995. Bioaccumulation of polycyclic 448 aromatic hydrocarbons by marine organisms. In: Wae GW (ed.) Rev. Environ. Contam. 449 Toxicol. 143, 79-166.

450 Neff, J.M., Cox, B.A., Dixit, D., Anderson, J.W., 1976. Accumulation and release of 451 petroleum-derived aromatic hydrocarbons by four species of marine animals. Mar. Biol. 38, $452 \quad 279-289$.

453 Neff, J.M., 1979. Polycyclic aromatic hydrocarbons in the aquatic environment. Sources, fates 454 and biological effects. Applied science publishers Ltd. Ripples road, Barking, Essex, England, $455262 p$.

456 Obana, H., Hori, S., Nakamura, A., Kashimoto, T., 1983. Uptake and release of polynuclear 457 aromatic hydrocarbons by short-necked clams (Tapes japonica). Water Res. 17, 1183-1187.

458 O'Connor, T.P., 1996. Trends in chemical concentrations in mussels and oysters collected 459 along the US coast from 1986 to 1993. Mar. Environ. Res. 41(2), 183-200. 
460 O'Connor, T.P., Lauenstein, G.G., 2006. Trends in chemical concentrations in mussels and 461 oysters collected along the US coast: update to 2003. Mar. Environ. Res. 62(4), 261-285.

462 OSPAR (2010) OSPAR Coordinated Environmental Monitoring Programme (CEMP). 463 Agreement 2010-1. OSPAR Commission, 27p.

464 Palmork, K.H., Solbakken, J.E., 1981. Distribution and elimination of $\left[9-{ }^{14} \mathrm{C}\right]$-phenanthrene 465 in the horse mussel (Modiolus modiolus). Bull. Environ. Contam. Toxicol. 26, 196-201.

466 Pereira, W.E., Hostettler, F.D., Rapp, J.B., 1992. Bioaccumulation of hydrocarbons derived 467 from terrestrial and anthropogenic sources in the Asian clam, Potamocorbula amurensis, in 468 San Francisco Bay Estuary. Mar. Pollut. Bull. 24, 103-109.

469 Phillips, D.J.H., 1976. The common mussel Mytilus edulis as an indicator of pollution by 470 zinc, cadmium, lead and copper. II. Relationship of metals in the mussel to those discharged 471 by industry. Mar. Biol. 38, 71:80.

472 Pritchard, J.B., Bend, J.R., 1991. Relative roles of metabolism and renal excretory 473 mechanisms in xenobiotic elimination in fish. Environ. Health Persp. 90, 85-92.

474 ROCCH 2008. Résultats de la Surveillance de la Qualité du Milieu Marin Littoral, Edition 475 2008. Résultats acquis jusqu'en 2007. Ifremer/RST.LER/MPL/08.02/Laboratoire 476 environnement ressources de la Trinité-sur-Mer, 78 p.

477 Solé, M., Porte, C., Barcelo, D., Albaigés, J., 2000. Bivalves residue analysis for the 478 assessment of coastal pollution in the Ebro Delta (NW Mediterranean). Mar. Pollut. Bull. 40, $479 \quad 746-753$.

480 Stegeman, J.J., Hahn, M;E., 1994. Biochemistry and molecular biology of monooxygenases: 481 current perspectives on forms, functions and regulation of cytochrome P450 in aquatic 482 species. In: Malins D.C. and Ostrander G.K. (Eds), Aquatic Toxicology: Molecular, 483 Biochemical and Cellular Perspectives. Lewis Publishers, Boca Raton, FL, pp 87-206. 
484 Vandermeulen, J.H., Penrose, W.R., 1978. Absence of aryl hydrocarbon hydroxylase (AHH) 485 in three marine bivalves. J. Fish Res. Board Can. 35, 643-647.

486 Varanasi, U., Reichert, W.L., Stein, J.E., Brown, D.W., Sanborn, H.R., 1985. Bioavailability 487 and biotransformation of aromatic hydrocarbons in benthic organisms exposed to sediment 488 from an urban estuary. Environ. Sci. Technol. 19, 836-841.

489 Varanasi, U., Stein, J.E., Nishimoto, M., 1989. Biotransformation and disposition of 490 polycyclic aromatic hydrocarbons (PAH) in fish. In: Varanasi U. (Ed.). Metabolism of 491 polycyclic aromatic hydrocarbons in the aquatic environment. CRC Press, Boca Raton, FL, 492 pp. 94-149.

493 Wade, T.L., Atlas, E.L., Brooks, J.M., Kennicutt, M.C., Fox, R.G., Sericano, J., Garcia494 Romero, B., DeFreitas, D., 1988. NOAA Gulf of Mexico status and trends program: trace 495 organic contaminant distribution in sediments and oysters. Estuaries 11, 171-179.

496 Watanabe, S., Shimada, T., Nakamura, S., Nishiyama, N., Yamashita, N., Tanabe, S., 497 Tatsukawa, R., 1989. Specific profile of liver microsomal cytochrome P450 in dolphin and 498 whale. Mar. Environ. Res. 27, 51-65. 

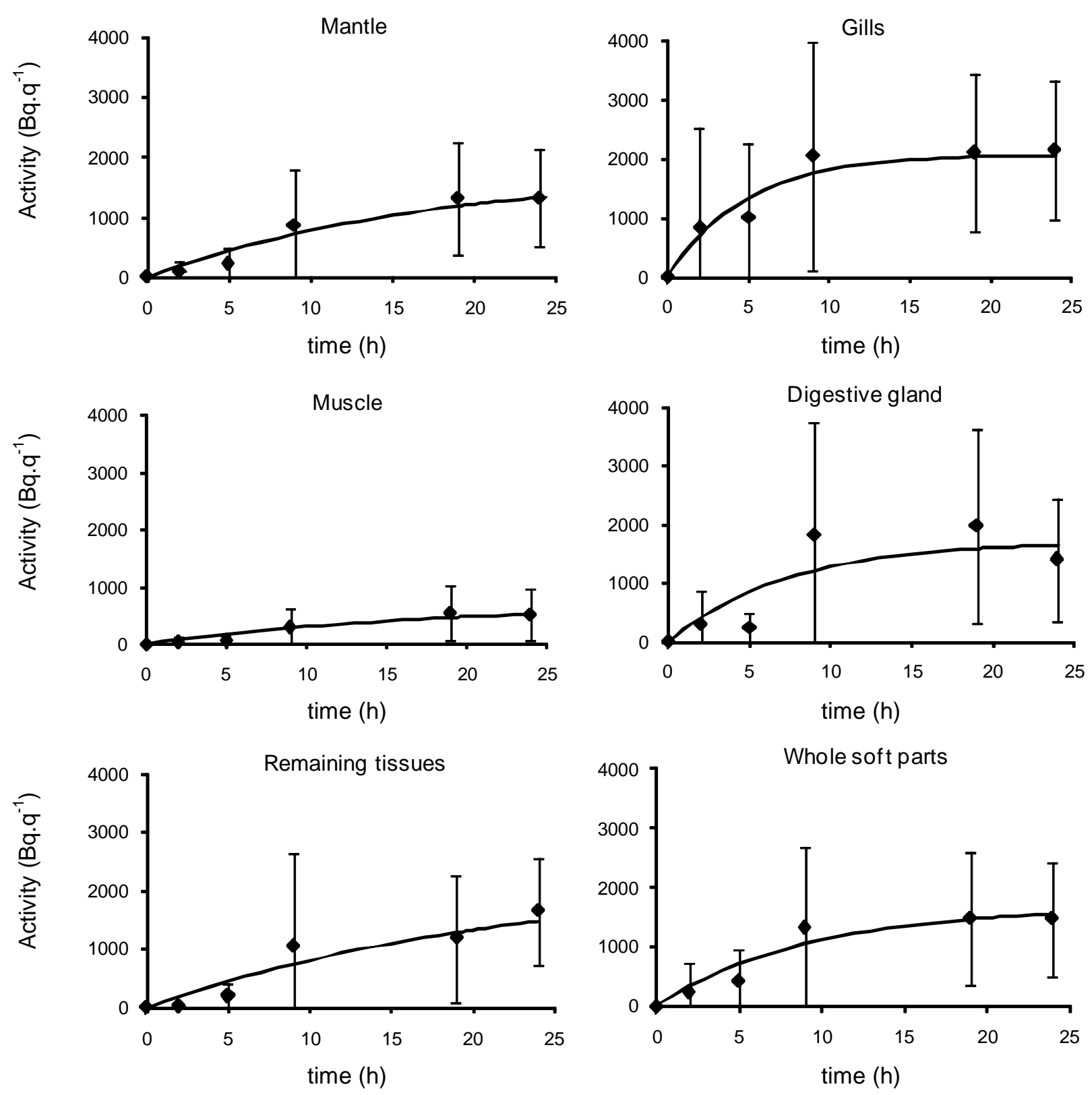

Figure 1: Uptake kinetics of ${ }^{14} \mathrm{C}$-labelled pyrene in five body compartments and in the whole soft parts of the oysters $(n=4)$ during the $24 \mathrm{~h}$ seawater contamination period. Parameters and statistics of the uptake kinetics are given in Table 1. 


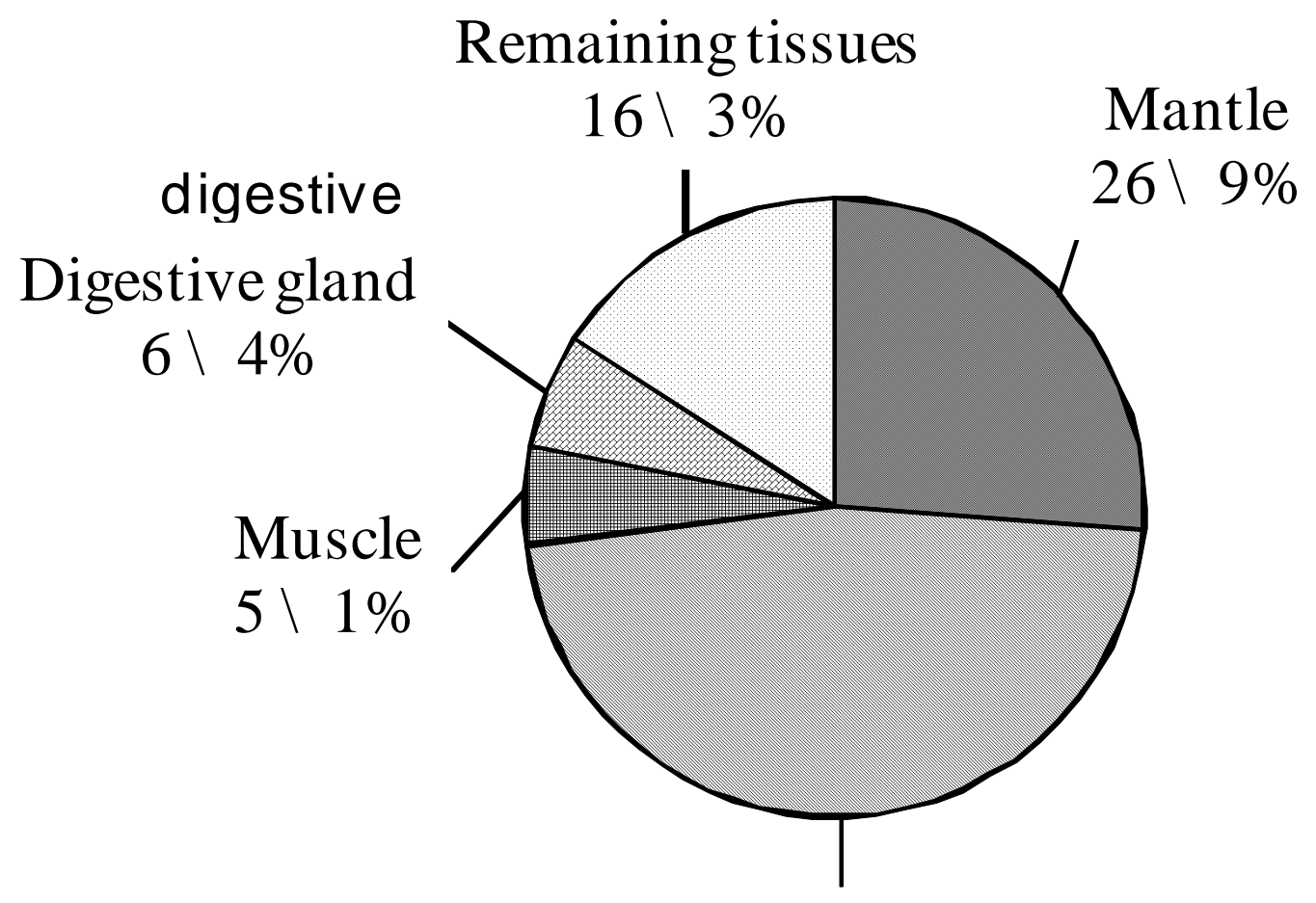

Gills

$47 \backslash 13 \%$

Figure 2: Distribution of ${ }^{14} \mathrm{C}$-labelled pyrene (\%) among the body compartments of oysters $(n=4)$ at the end of the exposure period $(24 \mathrm{~h})$. 


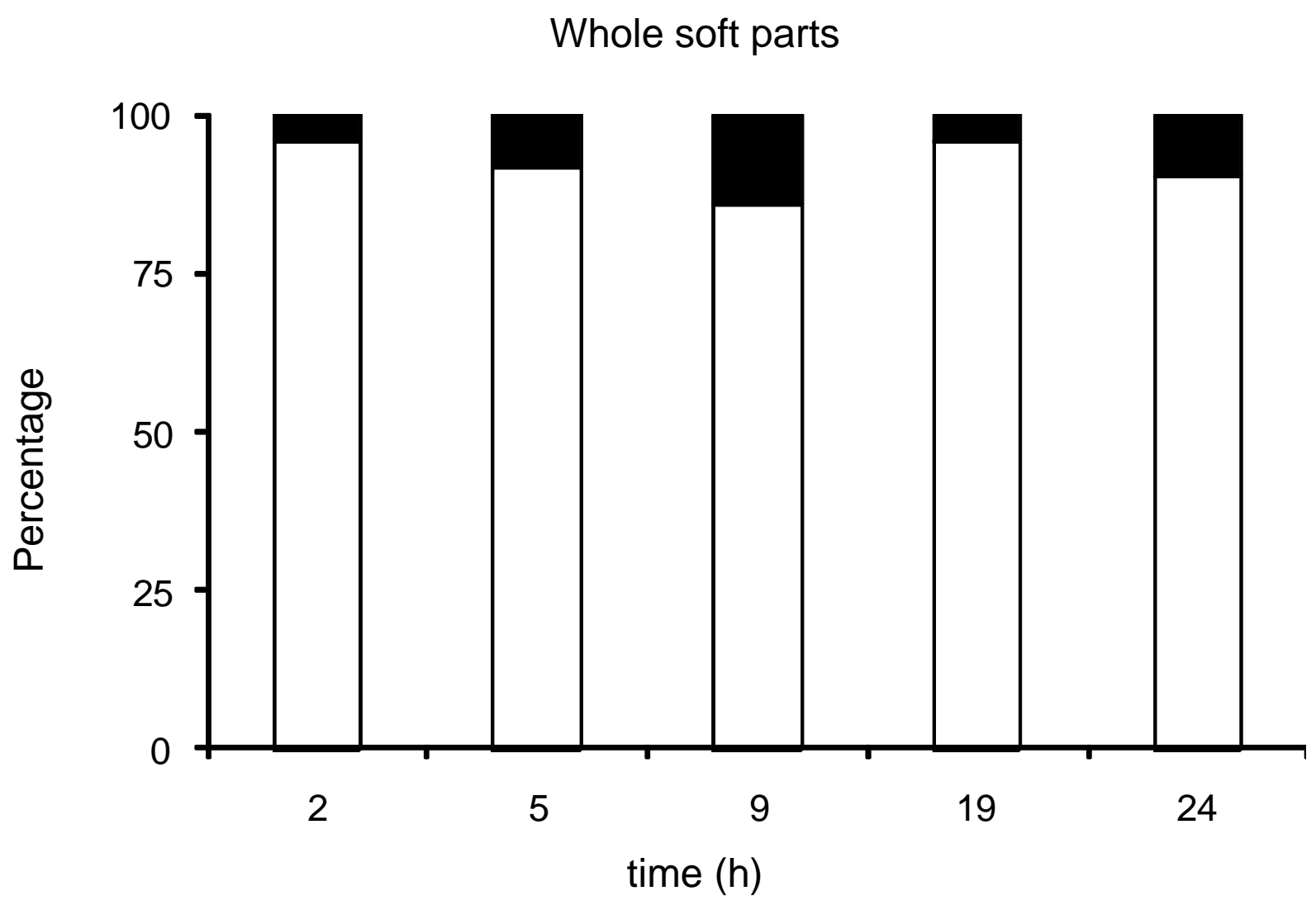

Figure 3: Proportion (\%) between ${ }^{14} \mathrm{C}$-labelled pyrene (in white) and 1-hydroxypyrene (in black) in the whole soft parts of the oysters $(n=4)$ at the end of the exposure period $(24 h)$. 

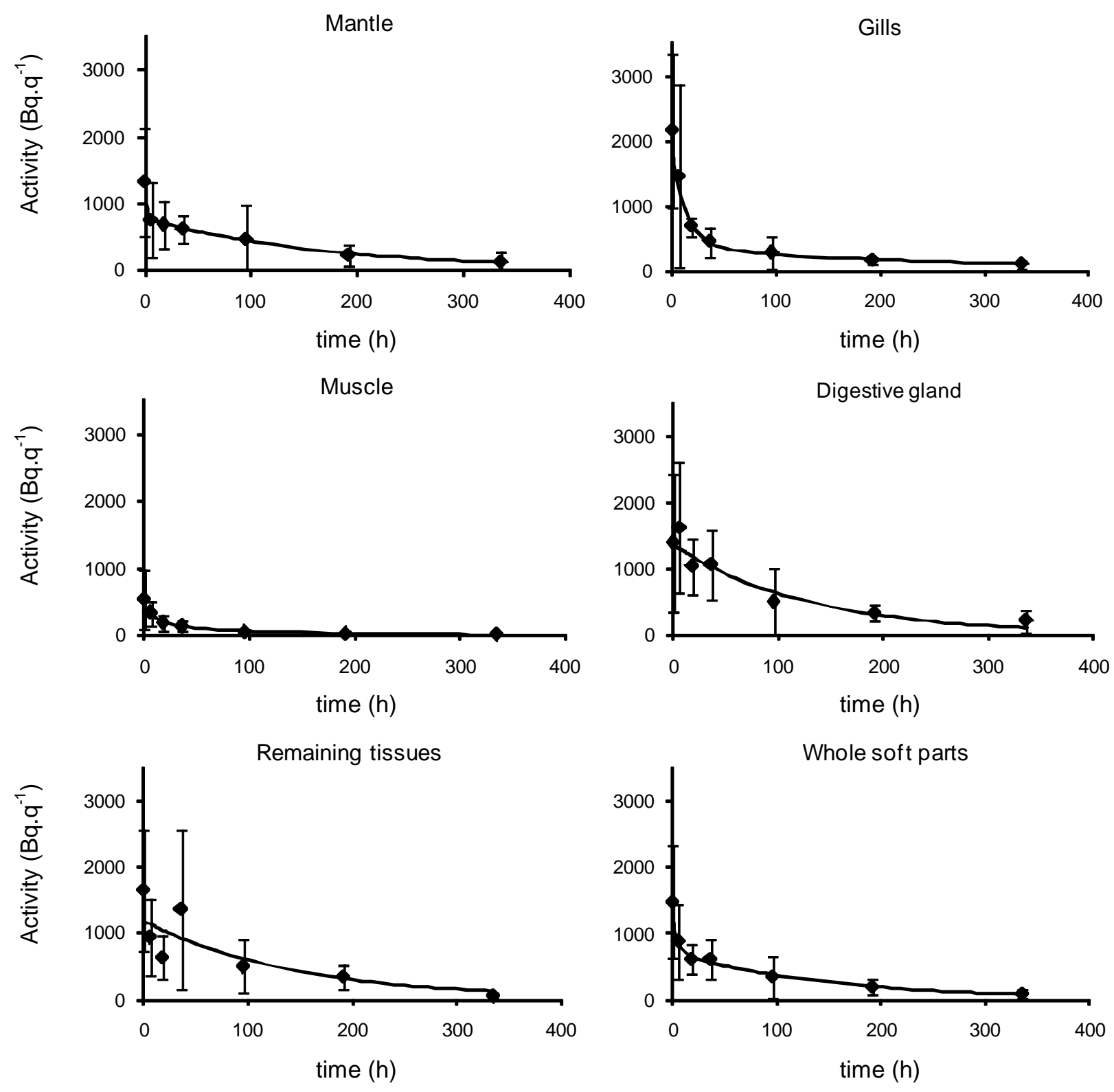

Figure 4: Loss kinetics of ${ }^{14} \mathrm{C}$-labelled pyrene in five body compartments and in the whole soft parts of the oysters $(n=4)$ after a $24 \mathrm{~h}$ seawater exposure. Parameters and statistics of the loss kinetics are given in Table 2. 


\section{Pyrene}

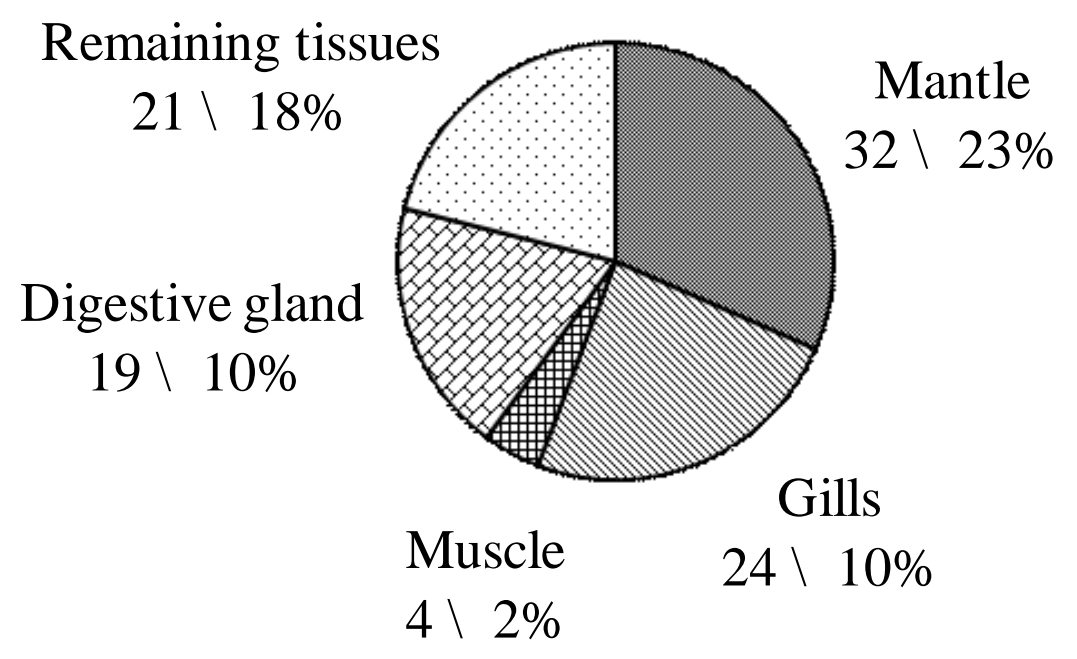

\section{OH-pyrene}

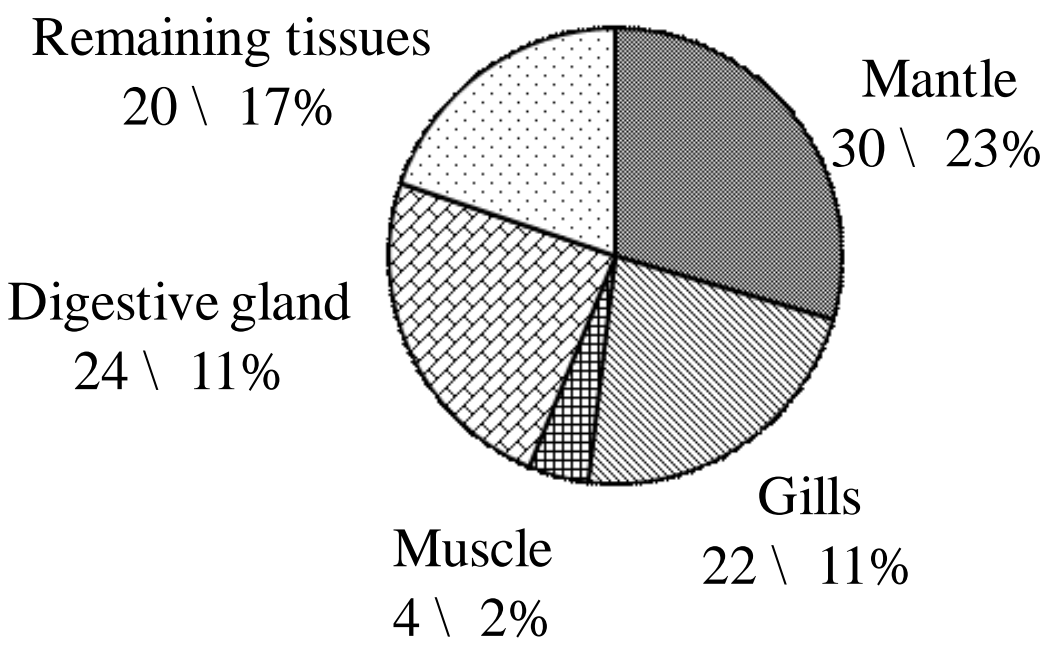

Figure 5: Distribution (\%) of ${ }^{14} \mathrm{C}$-labelled pyrene and 1-hydroxypyrene among the different body compartments of the oysters $(n=4)$ at the end of the depuration period $(15 d)$. 
Table 1. Parameters of the equation describing the uptake of pyrene in the body compartments and in the whole soft parts of the oysters $(n=4)$ after $24 \mathrm{~h}$ seawater contamination $\left(\mathrm{k}_{\mathrm{u}}=\mathrm{uptake}\right.$ rate constant; $\mathrm{k}_{\mathrm{e}}=$ elimination rate constant; $\mathrm{BCF}=\mathrm{Bioconcentration}$ factor)

\begin{tabular}{|lcccc|}
\hline Body compartment & $\begin{array}{c}\mathrm{k}_{\mathrm{u}} \\
\left(\mathrm{Bq} \mathrm{g}^{-1} \mathrm{~h}^{-1}\right)\end{array}$ & $\begin{array}{c}\mathrm{k}_{\mathrm{e}} \\
\left(\mathrm{Bq} \mathrm{g}^{-1} \mathrm{~h}^{-1}\right)\end{array}$ & $\begin{array}{c}\mathrm{BCF} \\
\left(\mathrm{k}_{\mathrm{u}} / \mathrm{k}_{\mathrm{e}}\right)\end{array}$ & $\mathrm{R}^{2}$ \\
\hline Mantle & $102 \pm 10$ & $0.056 \pm 0.006$ & $1820 \pm 530$ & 0.45 \\
Gills & $433 \pm 62$ & $0.208 \pm 0.030$ & $2080 \pm 860$ & 0.28 \\
Muscle & $38 \pm 6$ & $0.051 \pm 0.008$ & $750 \pm 380$ & 0.38 \\
Digestive gland & $234 \pm 50$ & $0.137 \pm 0.030$ & $1710 \pm 970$ & 0.26 \\
Remaining tissues & $100 \pm 12$ & $0.045 \pm 0.006$ & $2220 \pm 810$ & 0.35 \\
Whole body & $158 \pm 20$ & $0.101 \pm 0.014$ & $1560 \pm 630$ & 0.39 \\
\hline
\end{tabular}


Table 2. Parameters of the equations describing the loss kinetics of pyrene in the different oyster body compartments in the whole soft tissues $(\mathrm{n}=4)$ after a $24 \mathrm{~h}$ exposure from seawater. $\mathrm{O}$ and $\mathrm{T}$ : 1 - and 2-exponential loss equations, respectively; $\mathrm{A}_{0}$ : remaining activity at time 0 ; $\mathrm{k}_{\mathrm{e}}$ : depuration rate constant; $s$ : short and $l$; long-lived elimination, respectively; $\mathrm{R}^{2}$ : determination coefficient; $\mathrm{T}_{\mathrm{b} 1 / 2}$ : biological half-life in hours (h) or days (d). For abbreviation definitions, see 'Data and statistical analyses'

\begin{tabular}{|c|c|c|c|c|c|c|c|c|c|}
\hline Compartment & Model & $A_{0 \mathrm{~s}}$ & $\mathrm{k}_{\mathrm{es}}$ & $\mathrm{T}_{\mathrm{b} 1 / 2 \mathrm{~s}}(\mathrm{~h})$ & $A_{01}$ & $\mathrm{k}_{\mathrm{el}}$ & $\mathrm{T}_{\mathrm{b} 1 / 21}(\mathrm{~d})$ & $\mathrm{R}^{2}$ & $\mathrm{p}$ \\
\hline Mantle & $\mathrm{T}$ & 443 & 0.591 & 1.17 & 769 & 0.006 & 4.92 & 0.42 & $<0.001$ \\
\hline Gills & $\mathrm{T}$ & 1578 & 0.074 & 9.35 & 368 & 0.004 & 7.27 & 0.52 & $<0.001$ \\
\hline Muscle & $\mathrm{T}$ & 291 & 0.087 & 7.93 & 166 & 0.011 & 2.75 & 0.48 & $<0.001$ \\
\hline Digestive gland & $\mathrm{O}$ & 1360 & 0.008 & 87.4 & & & & 0.37 & $<0.001$ \\
\hline Remaining tissues & $\mathrm{O}$ & 1203 & 0.007 & 97.4 & & & & 0.30 & $<0.001$ \\
\hline Whole soft parts & $\mathrm{T}$ & 600 & 0.195 & 3.55 & 721 & 0.007 & 4.29 & 0.53 & $<0.001$ \\
\hline
\end{tabular}

